\title{
Vzpomínka na rok 1989 Ze sbírkového fondu Jihočeského muzea v Českých Budějovicích
}

\begin{abstract}
JiŘí Petráš
Abstract: A memory of 1989. From the collection funds of the South Bohemian Museum in České Budějovice

The goal of this study was to remind people of the period immediately following 17th November 1989. We wanted to point out the importance of previously overlooked museum collections in documenting our development, and draw attention to museums as a source of learning and knowledge. It was interesting to view the equipment and items used by students and the Civil Forum when addressing the public and promoting their ideas - posters, leaflets, film shots, various three-dimensional items, and also the technical equipment that strike committees used during their work. The second important part of the study was analysis of three speeches by Mojmír Prokop, spokesman of the Civil Forum in České Budějovice, during the course of the first half of November and the beginning of December 1989 - we saw the impression his speeches gave (how they reflected the changing society-wide situation), his emphasis of various topics and their selection. The process by which these people became members of power structures, how they were co-opted into national committees on all levels and also into the Federal Assembly, was also interesting.
\end{abstract}

KEY words: Velvet revolution - Civil Forum - České Budějovice - Mojmír Prokop - South Bohemian Museum in České Budějovice

ConTaCTs: PhDr. Jiř́i Petráš, vedoucí oddělení společenských věd Jihočeského muzea v Českých Budějovicích, Dukelská 1, 37051 České Budějovice; e-mail: petras@muzeumcb.cz

Události konce roku 1989 v Čechách byly ve třicátém - výročním - roce zpracovány a popsány ze všech možných i nemožných úhlů, byli jsme svědky mnoha zajímavých i ,zajímavých“ dokumentů, svědectví, názorů na to či ono, mohli jsme zaregistrovat i takové jevy, jako je nárůst počtu revolucionářů (údajně aktérů listopadových událostí) a jejich hrdinství. Člověk musel - byv zaplaven informacemi - vydat velké úsilí na jejich zpracování a roztřídění. Vzniklo a světlo světa spatřilo i mnoho knižních titulů, které leckdy v tom dobrém navazovaly na své předchůdce z posledních let. ${ }^{1}$ Navíc, jak jde čas, regionální komparativní

1 Např. Jiř́ Petrášs, Listopad 1989 ve světle pramenů JKV KSČ České Budějovice, Výběr. Časopis pro vlastivědu a historii jižních Čech, XXXIV, 1997, č. 4, s. 301-307; TÝž, České Budějovice v roce 1989; in: Pavel Krákora a spol., Obnova demokracie v Československu po roce 1989, Praha 2010. Dokonalé zmapování jihočeského regionu v období od konce osmdesátých let dvacátého století až do konce roku 1990 přinesl grantový projekt Průběh Sametové revoluce ve vybraných městech Jihočeského kraje v komparativní perspektivě, podpořeného Grantovou agenturou České republiky, reg. č. 13-15049S. V jeho rámci vznikla celá řada studií a publikací, které vycházely z podrobného průzkumu centrálních i regionálních pramenů, kronik,

(C) 2020 Jiří Petráš, published by the National Museum. This work is licensed under the Creative Commons Attribution- 


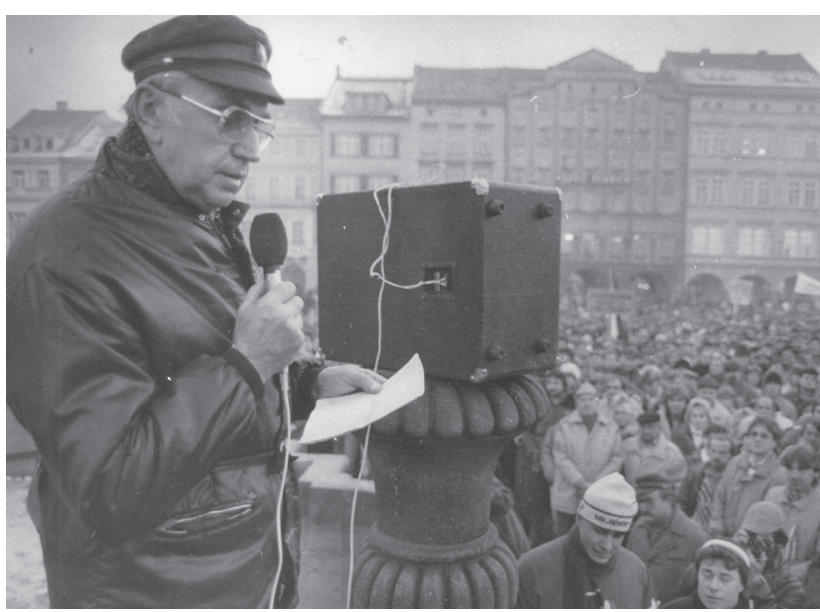

Obrázek 1 - Mluvči Občanského fóra v Českých Budějovicích RNDr. Mojmir Prokop při projevu v prủběhu generálni stávky 27. 11. 1989 (Jihočeské muzeum v Českých Budějovicích). literatury přibývá ${ }^{2}$, stejně tak jako je již vcelku dosti prací s obecnou tematikou ${ }^{3}$.

Můžeme na tomto místě říci, že řada titulů byla a je muzejní provenience. Je to celkem pochopitelné. Muzea jako pamětové, kulturní, ale i vědecké instituce mají ve svých sbírkových fondech potřebné materiály, které dosud pohř́íchu opomíjejí - ke své vlastní škodě - mnozí badatelé, kteří se soustřed’ují převážně na archivy. ${ }^{4}$

Také Jihočeské muzeum v Českých Budějovicích se může pochlubit velmi bohatým a v mnoha směrech i zajímavým souborem artefaktů k roku $1989^{5}$. Součástí souboru jsou např́klad amatérské filmové záběry z listopadových demon-

dobového tisku, z rozhovorů s narátory atd. Blíže a obsáhle k pramenné základně viz Lukáš VALEš, Úvod; in: L. Valeš - J. Petráš, Sametová revoluce v jižních Čechách, Plzeň 2017; Miroslava Pitrová-Kubatová, Obnova česko-rakouských př́hraničních vztahů na počátku 90. let 20. století; in: L. Valeš - J. Petráš a kol., Sametová revoluce $v$ českých obcích, městech a regionech aneb 25 let poté, České Budějovice 2014, s. 108-123; M. Pitrová-Kubatová - Pavel VÁlek, Pohled rakouského tisku na „sametové“ události v Československu; in: Scientia et Societas 2017/2, s. 101-117; Leoš NiKRMAJER, Česko-rakouské vztahy v jihočeských pohraničních okresech v období let 1989-1990; in: Východočeské listy historické 2017/2.

2 Např. P. KRÁKORA, Obnova demokracie v Československu po roce 1989, Praha 2010. Lukáš VALEŠ, Rok 1989 v Plzni a západních Čechách, Dobrá Voda 2003; TÝž, Zrod demokratických politických systémů okresů Klatovy, Domažlice a Tachov a jejich vývoj v 90. letech 20. století, Plzeň 2007; Přemysl JANíčEK - Petr ANDRÝSEK, Vzpominky na samet 89 nejen z Brna, Brno 2015; Jaroslav RoKoskx́, Sametová revoluce v Ústí nad Labem, svědectvi studentů po dvaceti letech, Ústí nad Labem 2009.

3 Za všechny jmenujme alespoň Milan OtáHAL - Zdeněk SLÁDEK, Deset pražských dnů 17.-27. listopad 1989, Praha 1990; Petr Pithart, Devětaosmdesátý, Praha 2009; Michal Pullmann, Konec Experimentu. Přestavba a pád komunismu v Československu, Praha 2011; Jiří SuK, Labyrintem revoluce. Aktérí, zápletky a křižovatky jedné politické krize od listopadu 1989 do června 1990, Praha 2003. Milan OtáHAL - Miroslav VANĚK, Sto studentských revoluci, Praha 1999.

4 Nedá se říci, že pramenů ke studiu by bylo, v našem př́ípadě pro Jihočeský kraj, málo; naopak, události na krajské stranické a státní úrovni (Jihočeský krajský výbor Komunistické strany Československa, Krajský národní výbor, Krajský výbor Národní fronty, Krajská odborová rada) jsou ve fondech Státního oblastního archivu v Třeboni, na úrovni okresu a města pak ve Státním okresním archivu v Českých Budějovicích a dalších okresních archivech. K dispozici je samozřejmě i Kronika Českých Budějovic za rok 1989 a též dobový regionální tisk.

5 Jihočeské muzeum v Českých Budějovicích, podsbírka historie, nejnovější dějiny, fond S. Z literatury blíže k tomu Jiří Petráš, Listopad 1989 ve světle pramenů JKV KSČ České Budějovice, Výběr. Časopis pro vlastivědu a historii jižních Čech, XXXIV, 1997, č. 4, s. 301-307; zejména ale TÝŽ, Výběrová edice pramenů k roku 1989 ze sbírek Jihočeského muzea v Českých Budějovicích, Jihočeský sborník historický, supplementum 9. Jihočeské muzeum v Českých Budějovicích 2018; Týž, České Budějovice v roce 1989; in: P. KráKora, Obnova demokracie v Československu po roce 1989, Praha 2010. 
strací (vč. generální stávky) ${ }^{6}$. Zvláštní místo pak zaujímá fragment železné opony - zhruba metrová část sloupu s ostnatým drátem byla v prosinci 1989 odstraněna ze svého místa na hraničním přechodu u Halámek a přenesena do muzejního depozitářre ${ }^{7}$. Nesmějí chybět samozřejmě ani plechové štítky, některé se smaltovým povrchem, se symboly Občanského fóra a odkazující i na podobné artefakty místní provenience z období Československého jara 1968. Na deníky či privátní písemné zpovědi však teprve (alespoň v Českých Budějovicích) čekáme.

Soubor materiálů Jihočeského muzea vztahující se k období 1989-1990 vznikl dílem vlastním sběrem (letáky, plakáty, různé trojrozměrné předměty, noviny, časopisy, fotografie), dílem darem občanů (především letáky a noviny) a především darem stávkového výboru studentů PF a VŠZ v Českých Budějovicích a českobudějovického centra Občanského fóra. Obsahuje řádově několik set předmětů různého druhu - denní tisk, fotografie, letáky, plakáty, tiskoviny Občanského fóra a studentského stávkového výboru a řadu dalších předmětů. Do muzea se tento soubor dostal díky osobním kontaktům pisatele této studie se členy studentského stávkového výboru. Dosti předmětů, tiskovin, zprostředkovala muzeu i tehdejší krajská redaktorka Svobodného slova, a to z dílny nakladatelství Melantrich a Československé strany socialistické. ${ }^{8}$

Prohlížíme-li si dnes fotografie z přelomových událostí konce roku 1989, které zabírají krajinu měst, můžeme si povšimnout jedné skutečnosti - množství plakátů a letáků, které byly vylepeny na všech možných i nemožných místech. Leták totiž slouží jako rychlá informace pro občany, pomáhá jim orientovat se v překotně se vyvíjející situaci a má je i udržovat v „bdělém“ stavu, leckdy má tendence manipulovat a nasměrovat mínění svých čtenářù. Pomáhá ale též poodhalit ducha doby, myšlenkový svět jeho tvůrců. Bylo tomu tak v našich moderních dějinách v srpnových dnech roku 1968 a opět i v událostech konce roku $1989 .{ }^{9}$

6 Jihočeské muzeum v Českých Budějovicích, podsbírka historie, nejnovější dějiny, fond S. Podobné amatérské záběry - tentokrát z Jindřichova Hradce - má v držení Muzeum Jindřichohradecka. Zcela jistě se filmové nahrávky nalézají i v jiných muzeích.

7 Jihočeské muzeum v Českých Budějovicích, podsbírka historie, nejnovější dějiny, fond S.

8 Jihočeské muzeum v Českých Budějovicích, podsbírka historie, fond S. V souboru se nalézají např́klad prohlášení pracovníků Kovopodniku České Budějovice (,,Studenti a umělci vydržte, jsme s Váma-pracovníci Kovopodniku“), Chirany OTS České Budějovice (,Jsme rozhodnuti v prripadě potřeby toto své stanovisko podpořit generální stávkou 27. 11. 1989, nebot’jsme přesvědčeni, že současné události v republice se nedotýkají jen zájmů studentstva, ale nás všech"), Jihočeských pekáren, Sdružení učitelů středních škol a ostatních školských pracovníků Jihočeského kraje (zástupci 49 středních škol a odborných učilišt’ Jihočeského kraje, kteří reprezentovali 778 členů Občanského fóra na svých pracovištích). V souboru jsou i prohlášení hokejistů Motoru České Budějovice (,, Vzhledem k naši neřešené politické a společenské situaci vyzýváme ke všeobecné diskusi a dialogu v duchu přestavby a demokratizace naši společnosti, který by pomohl najít východisko z katastrofální vnitrostátni situace. “), příslušníků vojenského útvaru 9664 České Budějovice (,,... za jednu z hlavnich naději považujeme hned vedle přstavby organizace řizení armády, př́pravu změny branného zákona a s tím souvisejici zkráceni délky základni vojenské služby). Své polínko si přiložila i dosud národněfrontová Československá strana lidová, jejíž krajský výbor v úvodu svého prohlášení napsal: ,, Vycházejíce z odvěkých mravnich zásad, které jsou vtěleny v křestanském poselstvi světu a v humanistické krest'anské filozofii, která stvořila evropskou kulturu a civilizaci, chápeme i dnešni události v naši zemi jako výzvu všem lidem dobré vi̊le k bratrství pred Bohem a tedy i k národnímu smíru mezi sebou. “

9 K tomu blíže viz J. PETRÁŠ, Výběrová edice pramenů k roku 1989 ze sbírek Jihočeského muzea v Českých Budějovicích, Jihočeský sborník historický - supplementum 9, Jihočeské muzeum v Českých Budějovicích 2018 . 
Součástí tohoto souboru materiálů studentského stávkového výboru v Českých Budějovicích jsou i tři projevy mluvčího českobudějovického Občanského fóra RNDr. Mojmíra Prokopa, které proslovil na náměstí Jana Žižky, a to ze dne 25. 11., 27. 11. a 8. 12.1989, a kterými se budeme dále zabývat.

Nejprve bude dobře seznámit se s RNDr. Mojmírem Prokopem. Povoláním meteorolog, byl amatérským pilotem, členem Aeroklubu v Českých Budějovicích, skautem a skautským vedoucím. Rodák z Krušovic (* 15. 4. 1928) prožil druhou světovou válku coby student gymnázia v Havlíčkově Brodě. Tam byl jeho otec pracovně přeložen. V prosinci 1945 se s rodiči přestěhoval do Českých Budějovic. Zde dokončil poslední ročník na gymnáziu v České ulici. Poté vystudoval na vysoké škole astrofyziku, astronomii, meteorologii a klimatologii. Po vysokoškolských studiích vyučoval fyziku na gymnáziu v Českých Budějovicích. Zde též začal létat v rámci Aeroklubu. V 60. letech pracoval zpočátku na oddělení fyziky oblaků a srážek AV v Hradci Králové, posléze získal místo na Vysoké škole zemědělské v Českých Budějovicích, kde přednášel klimatologii, meteorologii a zemědělskou meteorologii. $\mathrm{V}$ průběhu normalizace mu byly tyto aktivity na dalších dvacet let zakázány nemohl ani létat, ani přednášet na VŠZ. Coby důchodce (od roku 1988) se začal po 17. listopadu 1989 angažovat v budějovickém OF, které pomáhal zakládat. V únoru 1990 byl zvolen nejprve poslancem MěstNV České Budějovice a hned poté zvolen předsedou MěstNV. Tuto funkci (už coby starosta města Českých Budějovic) vykonával až do komunálních voleb, které se uskutečnily 24. 11. 1990. Do volebního klání nezasáhl, stáhl se z veřejného života.

Na tuto životní etapu po 17. 11. sám Mojmír Prokop vzpomíná: „, Nebyl jsem 17. listopadu v Praze, dozvěděl jsem se to tady v Budějovicích. A pochopitelně jsem se sebral a pádil tady na Vysokou školu zemědělskou. Ale ne ten den první, ale až ten druhý, poněvadž jsem se nejdřvive pídil po informacích, abych jich mél co nejvíc. No a vyrazil jsem za známými a přáteli, kteři ještě učili v té době na fakultě, kdy už já jsem byl pryč. Ale byli to moji dobř́ známí. Šel jsem se podivat, co na to tady Budějovičáci. No a narazil jsem na rybník ticha. Nic se tady nedělo. Takže jsem se pokoušel to trochu rozhýbat. Dneska už zemřelý profesor Zvára, to byl mi̊j dobrý kamarád z dob, kdy jsem tady působil, takjsem mu zavolal a zeptal se: ,Jožko, co délají študáci a fakulta?' Řikal, že tady se nic moc neděje. Já na to, že to je strašná chyba. Ǩikal jsem mu, aby se nebáli a šli do toho, že není rok 1968. No tak on slíbil, že se obrátí na nějakou studentskou radu, která se tak pomalu začala formovat. No a skutečně se fakulta potom taky rozjela a účastnila se těch akci na náměstí a podpořila tu akci mohutně. Hlavně ta část VŠZ, než z Pedagogické fakulty. Tam to byla účast poněkud vlažnější. Až na některé jednotlivce, kteři se angažovali naplno...

Prvni demonstrace [21. 11. 1989] byla taková, poněvadž bylo slyšet, že divadla v Praze byla prvni a tady u nás taky. Šel jsem kolem Malého divadla a měl jsem tam nějaké známé, poněvadž tam žena léta pracovala, takjsem se šel zeptat, co se děje. No a tehdy Ivan Třiska ř́ká: ,To je dobře, že sěs tady, už jsme sehnali technické prostředky, budou mikrofony, budou megafony, budeme na náměstí, koukej si jit připravit nějakou řěr. 'Já jsem jenom něco zakoktal, ale on řikal: ,Nepovídej, víš, co máš řikat, budeš na náměstí.' Skutečně jsme na to náměstí vyšli, nevím, kolik bylo hodin... No,... lidi začinali chodit z práce [demonstrace začala v 16.00 hodin - pozn. J. P.]. Tak se začalo pár lidí shromažd’ovat kolem kašny ze zvědavosti, poněvadž tam byl mikrofon a nějaký přenosový krámy, velký bedny, reproduktory. 
No a co si pamatuju živě, na každé části toho náměstí stál jeden policista, jeden esenbák, jak se tehdy ř́kalo, pohupoval se s pendrekem, ale nic nedělal. Nijak nezasahovali. Lidi ale stáli v podloubi a kousek pred ním směrem doprostřed náměstí, ale ke kašně moc lidí nechodilo... Aby mohli včas zdrhnout.

No ale postupně opadával ten strach. A jak je to začalo zajímat, začali přicházet bliž. No na té prvni demonstraci se nesešlo moc lidí. Ale hned ty další, to rostlo lavinovitě. Až bylo to náměstí úplně plný. Ale nechtějte po mně jednotlivé dny. To už si opravdu nepamatuju...

Fungoval jsem jako mluvči Občanského fóra a byl jsem jeden z těch, kteři se domnívali, že tvoři zárodek Občanského fóra. Čili jsem tam byl od hodiny nula... Bylo nás pár lidí. Kdybych to měl počitat, dneska zpátky, tak tam nebylo víc, jak osm devět lidí, kteři tvořili to ,tvrdý jádro ' Občanského fóra, když bych to takhle nazval. Jako organizátor se tam velice angažoval, a dobře, herec malého divadla Ivan Tř́ska. Ten to začal vést téměr takovým vojenským zpưsobem. Takže když někdo přicházel z toho vedení, tak velel vztyk a pozor - dělal z toho tak trochu ,kšandu'. Dál tam byl Vlach, Jiři Vlach, Jiř́ Pospíšil... Marta Zavřelová tam byla. Kdo tam byl ještě... Přizvali jsme tam samozřejmě studenty. Byl tam ten, kterej to ve Čtyráku u studentů všechno vedl... takovej drobnej kluk, trochu rezatej... Už si bohužel nevzpomenu, jména mi vypadávají už z paméti. Byli tam i lidi z fakult. Dva nebo tři lidi tam byli z pedáku, asi tři lidi tam byli z VŠZ. Vím, že to dohromady dávalo asi tak dvanáct lidí. Vic jak dvanáct lidí to $v$ tom samotném začátku nebylo. Pak se to rozrostlo nějak. Ale my jsme si hrdě ř̉kali koordinační centrum Občanského fóra pro České Budějovice.

Začali jsme kontaktovat okresy. Chtěli jsme získat i zástupce z okresư, aby to mělo nějaký charakter krajského vedení, aby to bylo nějak organizovaný, aby to nebylo živelné... Sídlo jsme měli v budově tehdejši fakulty u Mlýnské stoky U Folprechtů [v roce 1989 byl v domě U Folprechtů Dům politické výchovy - pozn. J. P.]. Tam se to napřed nějak vyklizelo. A jak jsme se tam dostali? Vzniklo to asi úplně spontánně, poněvadž se řeklo, že žádná politická výchova stejně neexistuje. Je tady úplně jiná éra, potřebujeme prostory, tak je zabereme. Nepamatuji se, že by někdo řekl, že tam nesmíme být. My jsme neobsadili celý barák, samozřejmě, jenom část. Potřebovali jsme psaci stroje, potřebovali jsme rozmnožovačky, nějaký cyklostyl. A to bylo všechno tam. "10

Mojmír Prokop se následně stal prvním nekomunistickým předsedou Městského národního výboru v Českých Budějovicích: „Byl jsem pozvaný na radnici. To už bylo poté, kdy během jednoho mého projevu, nebo na začátku, z jednoho rohu náměstí se ozvalo: ,Prokop na radnici!' a přerostlo ve skandování. Takže z tohohle titulu nějak... jsem byl vyslán na tu radnici, abych projednal nějaké věci, co se dál bude dit. No a tehdy se odehrávala taková zajímavá věc - sice tam ten návrh, abych se stal starostou, byl, ale muselo to projít volbou. Já jsem o tom neměl představu, jak. Někdo z těch stávajicich lidi, kteři na té radnici seděli, řkl, že je to jednoduché, že udéláme doplňovací volby. Zeptali se mě, ve kterém obvodu bydlím, vypsaly se volby pro ten obvod, vypsali jsme dvě tři setkání s voliči. Tam jsem zopakoval svoje vize, jak si to predstavuji, že by to mělo vypadat dál. No a odfajfkovalo se to a nakonec v tom... domě KV KSČ, krajského výboru, bylo slavnostní zasedání, dole v tom sále.

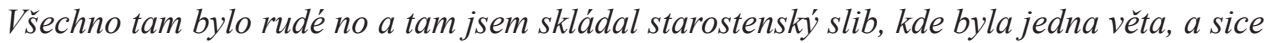
ta, že budu sloužit své vlasti Československé socialistické republice. Řekl jsem, že slovo

10 Rozhovor s Mojmírem Prokopem vedl Jiří Petráš dne 16. května 2013. 


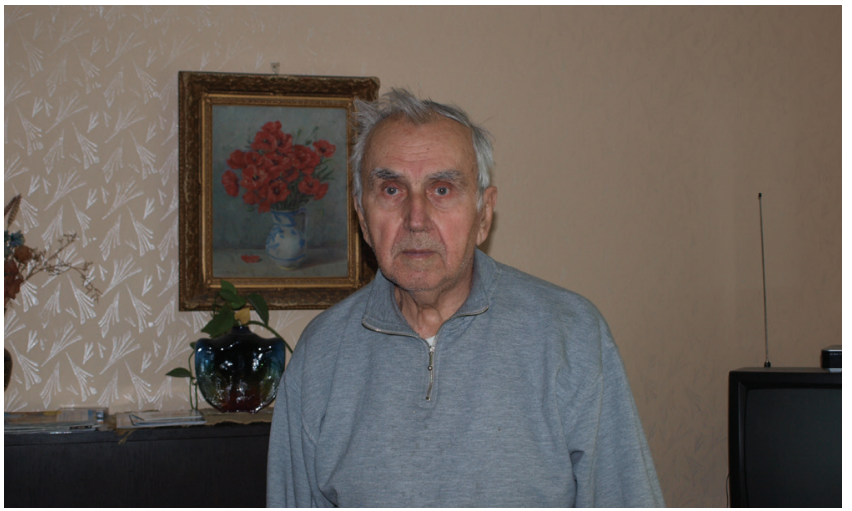

Obrázek 2-Mojmir Prokop, 2013 (foto autor).
„, socialistická“ ríkat nebudu. Řekli mi, že by to pak nebylo platné... To byla úplná groteska. No tak... po složení tohohle slibu, kde byli všichni poslanci stávající, ještě stará garda, tak tam se tohle odehrálo oficiálně, a tím pádem jsem se stal starostou. To byl prosinec. Poněvadž asi od 9. ledna jsem tam začal fungovat. "11

V současné době žije Mojmír Prokop v Českých Budějovicích, vzhledem k úctyhodnému věku, v ústraní. Kromě úzké skupiny lidí, kteří mají koníčka bud’to v létání, či v moderní regionální historii, či na něj vzpomínají z působení v místním OF, dnes jeho jméno nikomu nic neřekne. To je také důvod, proč se v této studii věnujeme jemu a jeho třem dochovaným a zdokumentovaným projevům.

Mluvčí českobudějovického OF hovořil k lidem z kašny každý den od úterý 21. 11. 1989, jeho projevy byly jaksi automaticky očekávány a patřily vždy $\mathrm{k}$ vrcholům každé demonstrace resp. generální stávky. Myslím, že byl ceněn i pro kultivovanost projevu (bylo znát, že mluví zkušený, sečtělý člověk s bohatými životními zkušenostmi a jasných morálních zásad), svou uvážlivost, kdy se např́klad snažil uklidnit dav, dostal-li možnost promluvit někdo z tehdy velmi neoblíbených oficiálních představitelů města resp. stranických činitelů (především v průběhu generální stávky). Měl samozřejmě co říci i při veřejných debatách OF s občany města, které se několikrát na přelomu listopadu a prosince konaly ve velkém sále DK ROH na náměstí 1 . máje. ${ }^{12}$ Zachovalé projevy pocházejí každý z trochu jiné etapy „Sametové revoluce“ - ze závěru úvodního revolučního týdne, z generální stávky, kdy se situace definitivně začala lámat $\mathrm{v}$ neprospěch dosavadních elit, a konečně z období, kdy se měnilo vládní složení a KSČ již byla na vedlejší koleji, byla už pouze jednou ze stran rodícího se nového politického systému (byt' ještě její představitelé zastávali řadu významných funkcí, faktický vliv však byl již v držení někoho jiného).

Na tomto místě je zajímavé povšimnout si i jednoho zdánlivého detailu: jakým způsobem byly rozmnožovány letáky stávkujících studentůำ. A s údivem zjišt’ujeme, že ke kopírování

11 Tamtéž.

12 Dnes Dům kultury Metropol, náměstí přejmenováno s platností od 1. 1. 1992 na Senovážné. Blíže ke změně názvů některých ulic a náměstí v Českých Budějovicích po roce 1989 viz Daniel KovÁŘ - Pavel KoBLASA, Ulicemi města Českých Budějovic, Jelmo 1998.

13 Zde je namístě připomenout situaci konce osmdesátých let 20. století. Tzv. kopírky byly v Československu horkou novinkou na konci dekády. Soukromé osoby si o nich mohly nechat jen zdát, přídělově je dostávaly pouze vybrané instituce. Když si chtěl kdokoli cokoliv okopírovat, namnožit, musel využít služeb k tomu vybraných středisek ve městě - avšak pouze po předložení občanského průkazu a zdůvodnění účelu kopírování (byt' toto bylo s postupujícím časem jakkoliv formální). Počítače byly v plenkách a bylo téměř nemyslitelné, aby se tato moderní technika objevila na stole v bytě obyčejného člověka. V podnicích byly nejčastější formy množení resp. kopírování formou tzv. rotaprintů či cyklostylů. Tyto přístroje stály uzamčeny ve zvláštních 
materiálů, letáků, používali prakticky okamžitě vedle běžných psacích strojů i psací stroje elektrické (nelze vyloučit, že i s pamětí), a dokonce počítače, kdy se tisklo na po stranách perforovaný papír na jehličkových tiskárnách! Jak k tomu tito „obyčejní lidé“ přišli? Z mnoha vzpomínek, at' již psaných, či mluvených víme, že tuto tehdy moderní techniku mohli využívat díky benevolenci, či př́imo spřízněnosti některých vysokoškolských učitelů či přímo i funkcionářr̆. A dá se předpokládat, že v jednotlivých podnicích, kde byla ustavena občanská fóra, tomu bylo stejně.

První zachovaný projev je ze soboty, 25. 11. ${ }^{14}$ Je přeplněn rozkošatělými souvětími, která jsou plná různých přirovnání. Jde o apelativní patetický projev, připomíná rok 1968, hrdiny domácího i zahraničního odboje 1939-1945 a jejich pronásledování komunistickým režimem po roce 1948. Současně varuje komunistické elity před převlékáním kabátů. ,,Vážení prátelé, proživáme vzrušené dni plné napětí, nadějí i nejistot a mnozi snad i strachu z toho, co bude dál. Nebudeme však malověrní a váhavě vyčkávajíci - nečekejme, že vytoužená svoboda nám sama spadne do klína. Bud’me stateční a stůjme pevně semknuti. Nastal čas, kdy je konečně na nás všech, abychom řekli své rozhodné ne!! Nejen policejní zvůli, pendrekovému režimu moci, nýbrž i šírení lži, strachu a násilí v elegantním obalu pokryteckých frází. Připadá mi často, že plujeme mořem intrik, licoměrnosti a nactiutrhání. Nabízeli jste dialog a dostalo se Vám cynického výsměchu v podobě surového násilí. Jímá mne hrůza při pohledu na záběry ze 17. 11. Vy mocní jste měli při tom ústa plná slibů, avšak za zády jste drželi v jedné ruce karabáč a v druhé řemení vzpouzejících se psů. Nepochopili jste vi̊bec nic z posvátného odkazu 17. 11. 1939 a pošlapali jste památku nejen v našich očích, ale v očích celé světové veřejnosti... Cituji! vite o co jde Vám i nám - nikdo se již nemůže vymlouvat na to, že byl sveden a od této chvile si každý z Vás píše svůj kádrový posudek. To neřikám já, ale cituji, prosím možná ne zcela přesně slova doktora Gustáva Husáka z roku 1969 - vidíte ne oko za oko, zub za zub, ale pamět!!! Ten citát pochází z počátku obdobi tzv. normalizace. A my chceme jít dál, také jenom normálnè, tak jak si jej dovolujeme znovu připomenout - jenom s jednou výhradou - my kádrovat nikoho nebudeme. ... “

Dvoustránkovou řeč končí patetickými slovy: „, A prosíme-li za odpuštění našich vin, jakož $i$ našich viniků nezbavujeme někoho odpovědnosti před pozemským zákonem za napáchané zločiny proti lidskosti. Nechceme mstu, ale spravedlnost pro naše dèti, pro naše nastupujíci mládí, aby se už nikdy nemuselo hrozit pod bičem skrytého i zjevného útlaku a mohlo ve svém životě naplnit ideály, které lidstvo hledá od nepaměti a jež dost dávno třeba formulovala Francouzská revoluce. Volnost-rovnost-bratrství. Ve víre v jejich uskutečněni predáme na závěr toto naše heslo PRAVDA ZVÍTĚZÍ!!! “ Je jasné, že celý projev směřoval k aktivizaci občanů před nadcházející generální stávkou.

místnostech, kam mohli pouze vybraní jedinci. Byla to práce velmi špinavá (uhlový papír popř. barva, které sloužily přímo jako kopírovací médium) a vesměs nezdravá. Nejčastějším a vlastně jediným běžným pomocníkem byl klasický psací stroj, který měl v této době i luxusní elektrickou variantu, a to i s omezenou pamětí (napsanou stránku měl schopnost napsat v několika kopiích).

14 Všechny tři projevy reprodukujeme v původním znění, včetně drobných chyb. Projev se zachoval ve dvou vyhotoveních. Jedno je psáno na obyčejném psacím stroji a rozmnožované pomocí cyklostylu, druhé psáno již na počítači a tištěné na (z obou stran po krajích) perforovaném papíru jehličkovou tiskárnou. Jihočeské muzeum v Českých Budějovicích, podsbírka historie, inv. č. S 15528. 
Na té vystoupil mluvčí českobudějovického občanského fóra s projevem kratším, ani ne polovičním ${ }^{15}$. Charakter proslovu odpovídá slavnostní situaci -,,Přátelé moji milí, mládeži

Když se tak na vás dívám, je mi nevýslovně dobře a zároveň se bojím, že nenajdu pro tuto chvili nejvhodnějši slova.

Nevím, jestli citite totéž co já, protože ve mně se obnovila víra ve vítězství dobra nad zlem i jinde než v pohádkách a hlavně víra v člověka.

Dokázali jste z chladnoucího popela, který zbyl na pohřební hranici národní hrdosti a cti, vykřesat jiskru - rozdmychat plamen a zapálené pochodně roznést po celé zemi.

Vlastním horoucím srdcem a jiskřicím duchem jste ten oheň živili až do těchto chvil. Národ vám nikdy nebude dost vděčný, dokázali jste téměr nemožné vy všichni bezejmenní pěšáci revoluce!

Vy všichni jak tu stojíte dnes, stejně tak jako včera a dny předtím jste se vlastně zasloužili o stát, o nové svobodné Československo!

I když si opakuji ta kouzelně znějicí slova stokrát za den, ještě nedokáži plně vstřebat jejich obsah a predstavit si, co všechno znamenají.

Nevím, jak jednou historie pojmenuje epochu, která je za námi, vím však, že ta nadcházejicí bude epochou obrody. My starši jsme na ni čekali dlouho vám mladším a mladým ze srdce přji, abyste v ní prožili plný a štastný život - přiznám se, že vám trochu závidím!

Nečekejte, že začátky budou snadné: sílu musite čerpat z ideálů, pro něž jste v minulých dnech tolik vykonali. Nikdy na ně nezapomeňte!

Já sám vám potom děkuji za to, že jste mi dovolili být s vámi a že jste přemýšleli o tom, co jsem, diky vám, směl vyslovit.

Odpust'te, prosím, jestli jsem někdy mluvil trochu dlouho, nebývalo to mým zvykem, ale myšlenky se valily jako peřeje na divoké řece.

Byl bych docela rád, kdybych $k$ vám již z tohoto mista mluvit nemusel-zejména ne za těch okolností jako dnes. Přál bych si, aby roli mluvčiho národa převzali brzy ti lidé a instituce, kteři a které by jimi měli být - nově zvoleni poslanci, nová národni shromáždění, nová vláda - jednoduše čerstvá krev, lidé schopni moudři a pracovití. Je na nás všech jak přiložíme ruku $k$ dilu.

Na duchovni frontě jste povstali, bojovali a vítězili, na té druhé frontě - politického boje jsme pripraveni vést zápas čestnými formami - tedy fair play - na jiné nepřistoupíme! Rozloučím se s vámi tak, jak se dř́ve u nás řikávalo: Dejž vám Bůh zdraví a sílu, abyste započaté dílo zdárně dokončili! "16 Nutno podotknout, že slavnostní atmosféra vládla celé generální stávce, která probíhala na hlavním českobudějovickém náměstí - a projev tomu odpovídal. ${ }^{17}$

15 Projev z 25. 11. je zachován v jedné variantě. Je napsán na obyčejném psacím stroji na tenkém průklepovém papíre. Jihočeské muzeum v Českých Budějovicích, podsbírka historie, inv. č. S 15528.

16 Tamtéž.

17 Blíže J. Petráš, České Budějovice v roce 1989; in: P. Krákora a kol., Obnova demokracie v Československu po roce 1989, Praha 2010. 
Poslední citovaný projev Mojmíra Prokopa je ze dne 8. 12. 1989. ${ }^{18}$ A významově se jedná zase o další posun. Řeč proslovená na fóru byla zjevně reakcí na instalování Adamcovy federální vlády 15:5, která měla jepičí život, a následná jednání o nové vládě a potažmo i novém presidentovi ČSSR ${ }^{19}$ Mojmír Prokop zde hovoří o KSČ (v čele s novým generálním tajemníkem Karlem Urbánkem) již jako o jedné z mnoha politických sil. Během několika málo dní vidíme zřjmý posun v politické realitě: „Pan Urbánek je však pouze jedním z předsedů politických stran navíc úplně zdiskreditovanou. Zásadně odmítáme účast generálniho tajemnika KSČ na jakémkoli jednáni, které př́sluši jen vládě ČSSR, KSČ reprezentuje jen bídu naši společnosti. "20

Druhá část projevu je reakcí, komentářem, k vystoupení předsedy vlády ČSSR Ladislava Adamce v televizi dne 6. 12. 1989. Mojmír Prokop ho ve svém projevu př́mo oslovuje, hovoří k němu, jako by byl premiér na demonstraci přítomen. Je sžíravý, nekompromisní, zjednodušující až - můžeme říci s odstupem - trochu zavádějící a manipulující: ,„Již v úvo$d u$ [televizního projevu dne 6. 12. 1989 - pozn. J. P.] se zmiňujete, pane předsedo vlády, o tom, že nepovažujete složení federální vlády za optimální a pro všechny vyhovující a že podle potřeby může být zkvalitňována ...

Převedeno do jadrnějši češtiny to znamená asi tolik jako, vědomě jsme vyrobili zmetek, ale časem ho trochu vylepšime!

Řečeno jinak: ,Sestavili jsme vládu, která určitě vyhovuje vedení KSČ a je nám také jasné, že jsme v dané situaci tímto krokem podráždili převážnou většinu národa.

Požádal jste představitele všech složek o návrhy, řikáte vy, chcete řici, že jste jich dostal tak málo, že z došlých jiná vláda sestavit nešla?

„Ne každému bylo vyhověno ' - ríkáte, ,s tím se musí počitat', někomu jste však přece jenom vyhověl zcela! Mưžete nám to vysvětlit?

$V$ situaci, v niž jsme, nesvědči to, co jste volil, jako kvalifikované rozhodnutí státnika s rozhledem, prípadně je to více jako hra v kostky nebo výprodej partiového zboži na výročním trhu!

Dále ř́káte, že není možné jednat pod nátlakem ultimát a že nemůžete jednat pod nátlakem jedné skupiny? Mohl byste tuto skupinu bliže specifikovat? - pokud by to měla být nekomunistická část veřejnosti, což lze z textu vycítit, nemáte zřejmě vi̊bec ponětí o veřejném miněni a doporučuji, abyste se rozhlédl důkladněji kolem sebe!

Kompromisni řešení, které hledáte, musí být přijatelné pro všechny, pro celý národ - nejen osobně pro Vás nebo menšinu, pane ministerský předsedo!

Dále mluvite o stupňováni napětí, které by mohlo těžce poškodit naši ekonomiku; jste si vědom, že toto napětí stupňujete osobně Vy sám rozhodnutím, které jste učinil?

18 Jihočeské muzeum v Českých Budějovicích, podsbírka historie, fond „S““. Dlužno podotknout, že u tohoto projevu chybí první strana. Projev byl psán tentokráte pomocí elektrického psacího stroje a zcela jistě byl také kopírován a rozmnožován.

19 O složitosti jednání mezi Ladislavem Adamcem a jeho poradci na straně jedné a Václavem Havlem a jeho nejbližšími spolupracovníky z řad OF, která se změnila v komplikovanou šachovou partii, viz např. J. SUK, Labyrintem revoluce. Aktéri, zápletky a křižovatky jedné politické krize (od listopadu 1989 do června 1990), Praha 2003; P. Pithart, Devětaosmdesátý, Praha 2009.

20 Jihočeské muzeum v Českých Budějovicích, podsbírka historie, fond „S“. 
Jaké jistoty každodenního života lidí jsou v nebezpeči - chcete ř́ci, že pekaři nebudou péci chleba, zhasnou světla a nastane konec světa, když padne vláda, kterou jste sestavil?

Přestane-li fungovat nefungujíci státní správa, mám dojem, že se tak moc nezměni!! Autobusy i vlaky budou jezdit i bez pana starosty - však on se někdo najde!

Kdybyste se snažil - jak řikáte - pane ministerský předsedo, každého pochopit, tak byste musel jednat jinak. S oblibou použiváte pro většinu národa termínu, určitá část společnosti '- chybi tam už jen dodatek, svedená imperialistickou propagandou '- a jsme doma!

Jak můžete být zastáncem právního státu, když jste dal prednost při sestavování federální vlády representantům strany, která sama o sobě prohlašuje, že až přiliš často jednala protiprávně. Za kým vlastně stojite - za stranickým štítem nebo za národem? ...

Jste-li pro co nejrychlejši uspořádáni demokratických voleb - tak my jsme raději pro svobodné volby, tomu rozumíme. Svérázné modely demokracií máme již snad jednou provždy za sebou!...

Změnit musite celé politické klima v zemi, to je úkol čísla jedna, pane ministerský predsedo; až lidé budou mít jistotu, že žijí ve svobodné zemi, lidsky, důstojně-potom věrte, že budou ochotní i utáhnout si opasek o pár dírek a ,makat ‘-jakékoliv opomenutí v tomto smyslu však může znamenat nejen konec iluzím o št'astném životě zítra - nýbrž i pro budoucí generace. "21

Závěr projevu věnuje tomu, co v následujících týdnech a několika měsících začne měnit politickou mapu Československa - procesu výměny poslanců zastupitelských sborů všech stupňů, od těch místních, až po federální. Odvoláváni byli, či přímo sami rezignovali „,zkompromitovaní“ poslanci bez důvěry voličů, a místo nich nastupovali noví lidé příslušníci jak stávajících tradičních politických stran (v České socialistické republice Československá strana lidová, Československá strana socialistická - tyto se velice rády a hbitě distancovaly od své národněfrontové minulosti), taktéž nestraníci, zástupci OF, či nových hnutí, spolků, stran a straniček, které vznikaly jako houby po dešti. Nutno podotknout, že v tomto období spatřilo světlo světa a bylo rozšiřováno mnoho těchto letáků, které často vypracovávali studenti právnických fakult vysokých škol. Byl to vlastně jakýsi návod, „manuál“" na výměnu nepohodlných poslanců a dosazení těch, kteří by byli zárukou dalších politických změn.

\section{„,Vážení občané,}

Je nesporné, že někteři poslanci zastupitelských orgánů zklamali důvěru nás, voličů. Máme na mysli např. tyto poslance Federálního shromážděni: Jakeš, David, Fojtik, Bilak, Hofman, Štěpán, Václavík, Kabrhelová, Češka, Slavík a další. Právní úprava pro odvolání poslanců je poplatná době, kterou se snažime změnit a tak postup je velmi složitý a prakticky nepoužitelný. V $\$ 49$ zákona o volbách do Federálního shromáždèní se uvádi, že poslanec, který zklamal di̊věru voličů nebo který se dopustil nedi̊stojného činu, müže být odvolán. Zkompromitovaní poslanci nenašli v sobě dostatek odvahy a síly přiznat si nezvratnou skutečnost, že ztratili ve smyslu zákona právo být ve Federálním shromáždění. Nevzdali se svého mandátu sami. Je potom odpovědností př́slušného orgánu předložit předsednictvu Federálního shromáždění návrh na jejich odvolání. Tyto orgány však jakoby nebraly prání a vi̊li voličů na vědomi a mlčí. Domníváme se, že je třeba dát jak

21 Jihočeské muzeum v Českých Budějovicích, podsbírka historie, fond „S“. 
těmto poslancưm, tak i př́slušným orgánům hmatatelný důkaz jednoznačné vůle a přání obyvatelstva, které zní: Nemáte náš mandát! "22

Ale proces odvolávání a výměny poslanců je již přece jenom jiná kapitola, která přesahuje rámec tohoto článku.

Naší snahou, ambicí, bylo nejenom připomenout období bezprostředně následující po 17. listopadu 1989, ale též i důležitost muzejních sbírek pro dokumentaci našeho vývoje, upozornit na muzea jako na jeden ze zdrojů poznání a vědění, který je badateli mnohdy přehlížen - ke škodě jejich i ke škodě poznání samotného. Zajímavé je sledovat samotné prostředky, předměty, jež použivali studenti a Občanské fórum při oslovování veřejnosti a propagaci svých myšlenek - plakáty, letáky, filmové záběry, různé trojrozměrné předměty. To se týká i techniky, kterou používali při výrobě a samotném rozmnožování, kopírování letáků a plakátů - v ničem totiž nezaostávala za technickými prostředky použivanými tehdejšími stranickými a státními elitami. Studentům pomáhali vyučující na vysokých školách (jistě ne všichni, samozřejmě; stejně tak by bylo naivní domnívat se, že studenti působili jako jednotný monolit - mnoho z nich odjelo z vysokoškolských center do svých domovů, kde v klidu svých pelíšků sledovali děje v televizi, či na hory, kde si užívali prvního sněhu), podporu nalézali ve svých rodinách a přicházela i od obyčejných neznámých lidí, kteří jim nosili (vedle pamlsků tuhého i tekutého charakteru) papír, kopírovací blány, dokonce i psací stroje, nebo pomáhali tím, že roznášeli a vylepovali po ulicích měst výzvy, plakáty, letáky... Důležitá byla pomoc morální, pocit sounáležitosti a spolupráce napříč generacemi i profesemi - mluvíme vlastně o občanské společnosti. Především jsme ale chtěli upozornit na to, že mezi námi žijí lidé, jejichž jména a je samotné je zapotřebí držet v paměti, vědět o nich. Historická pamět', jak se zdá, je krátká a úlohou nás, historiků, muzejníků, je ji prodlužovat.

Na následujicich stránkách obrázky 3-7 - Tištěné verze projevů Mojmíra Prokopa z listopadu/ prosince 1989 (Jihočeské muzeum v Českých Budějovicích).

22 Tamtéž. 
Váženi prátelé,

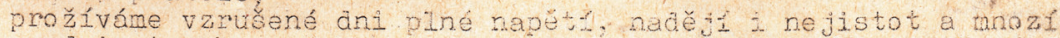
snad i strachu $z$ toho, co bude dál. Nobudeme vuak malovernń a váhavĕ vyčkávajíct - nečeke jme, že vytoužená svoboda nám sama. spadne do kina. Buăme statečnf a stijme perno semknuti. Na.. stal čas, kdy ja konežné na-nás väech, abychom rekli svojenoz.. hodné nel! nejen policejnl zvô7, , Dendrekovému režlmu moci, nýbrž i Gireni ližt strachu a násili v elegantim obalu pokryteckých frázi. Pripadé mi často, že plujeme mo rem intrik, licomernosti a nactiutrhánt. Nabizeli. jste-djalng a dostalo se ván oynického výsměchu v podobě surového nésill. Jráá ane hrüza prí pohledu

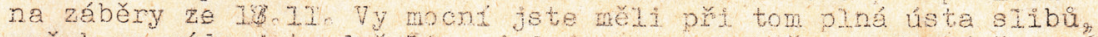

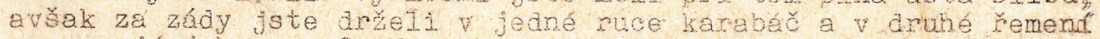
vzpouzejlolch se psí. Nepochop1li. jste vúbeo nio z josvátnébo odkai zu 17.11 1939 a poslapalt jste jeho pámátlu nejen v ndéich očich.

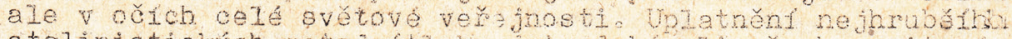
stalinistickych metod útlaku jete dokezelt, že humenita je vám cizlm pojmem Je to patmé zkknites jinak raysiet a jeanat jste nejmeli, nebot to byly práve tyto netody které vás vynesiy na

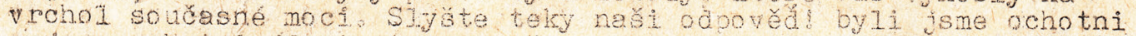
a jsme ochotni janat nikoliv väak o těmi, ktent se bruboce zdiskreditovali svým neobiombún vestojem a ötitivé odstrkovali ruku podávanou ke smiru a to na väech stupních rizeni státu. Zbylo Váth jenom jedno jediné! v tichosti odejit a nemanévrevat. Mnohá z prévi která jote si osobovali Vám nikdo nikdy redal. Na začátiku Vas̆l epochy jste se vídy p této zemi zmooniti násilía za pomocl zahraniend intervence, vládli jste opreni o bajonety a národ jste dokázali za ponéme krátkou historickou etapu jrivést. $\checkmark$ moha směrech na pokrá zouialstut. Vytýkére ném emoce, pla..

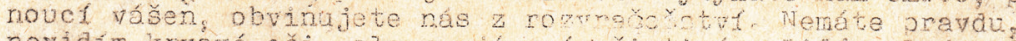
nevidim krvavé oéj, ale ro jásané céi tisice lids plné nadsuenf. Lidéé najednou na sebe začinají být hodnł a obledublní, pomáhajf́ si navzáfem jsou prí tom i phrin couti do poréané práce a dokazuji, jak vysoky morálni kredit lze probudit jakoby návnutím

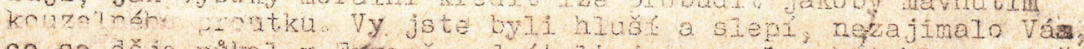
$c o$ se deje vikol v sropé, odmitali jste nastoucher hlasu zemé,

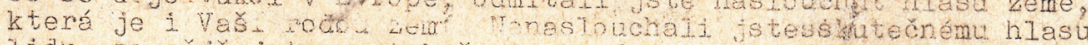
iidu, za néjz jste se tak dasto skryvali potoky frézi dokonale jste se odrdhli od obye yonénoclaveka a jebo etarostl visednfho dne a zhliželi na svět $z$ výsin jakśsi bohnová nedotknutelnosti. Loù pluje tam, kar se natodl komidlo, prosteppodie toho kdo je u vesla. To vesio i komidio jste dnzell - promtite mi ten temin - "setsakramentsky" diouho a ted se aivite, že se posádka lodi nemíni nechat utopit ve viru, který brozi strnnou vóechny Yás i nás. Nemiżete se vymul uvat ha to, ze nesvitily majiky, ba dokonoe hvězđa od vychodu tam ukazovala správnýsmer jenom

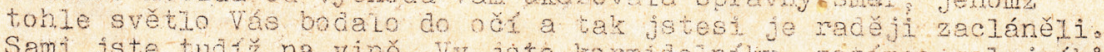
Sami fste tudĭ na vine, Vy jstê komideiniky, zátimeo galejníküm nebyio dovoleno nic vio ne mjcet a potit kfov. Nebudu dále mlúvit v motaforách, ale nazívat vécl pravini jmény: ptám sa Vás na en jste čekal? Snad na to, až sSsR Gorbačot padne i. perestrojka nebo na bratrskou ponge mimozemské civijizace, prom tože na jinol uź nelze spoléhat. ifte semi dobre ze tyto pred-.

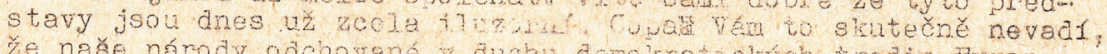
že nas̆e národy odchované v duchu demokretiokych tradic Ervop. ského donu se mus1 divat na tos jak nás v procesu demokratizace socialismu predstihuji snad vasohny sousedni zené. Ujiüdi nám. autobus, ale Vém to nic ne łká, ba doknoe se zdá, že víbec neminite nastoudit. c co Vám sio a o biaho yidu debo o pocit neomezrené mocl, na niz jste sl. benea desitek let zvykli jako na omamou drogu? Wevidite, jak se ze väch Stran ozývafi varovné hlasy, hrouti se chetrué zdd doktrin 1 paláce lǘl. 


\section{RBOJEY}

PANA RNDC MONḾRA PROKORA Y CESKÝCH BUDẺONICÍCH ZE DNE 25.11.1989

mluvčího českobudèjovického občanského fóra

Vážení přátelé, prožíváme vzrušené dni plné napětí i nejistot a mnozi snad $i$ strach z toho, co bude dál. Nebudme však malověrní a váhavě vyčkávající - nečekejejme, že vytoužená svoboda nám sama spadne do klína. Budme stateční, stủjme pevnè semknuti. Nastal ças, kdy je konećné na nás všech, abychom řekli svoje rozhodné NE!! nejen policejní zvưli, pendrekovému režimu, moci, núbrž i šírení lž́i, strachu a násili v elegantním obalu pokryteckých frází. Připadá mi často, že plujeme mơ̌em intrik, licomérnosti a nactitrhání. Nabízeli jste dialog a dostalo se vám cinického výsméchu v podobè surového násilí. Jímá mne hriza pŕi pohledu na zábéry ze 17.listopadu. Vy, mocni jste méli prới tom plná ústa slibư, avšak za zády jste drželi $v$ jedné ruce karabáč a $v$ druhé remení vzpouzejícich se psú. Nepochopili jste vủbec nic z posvátného odkazu 17.11.1939 a pošlapali jste jeho památku nejen v našich oćích, ale i $v$ oćich celé svètové verejnosti. Uplatnẻni nejhrubších stalinistických metod útlaku jste dokázali, že humanita je vám cizim pojmem. Je to patrné zákonité, jinak myslet a jednat jste neuméli, nebớ to byly právě tyto metody, které vás vynesly na vrchol současné moci. Slyšte tedy naśi odpovéd: byli jsme ochotni a jsme ochotni jednat, nikoliv však 5 tèni, kterí se hluboce zdiskreditovali svím neoblomnúm postojem a štítivé odstrkovali ruku podávanou ke smíru, a to na všech stupnich rizení státu. Zbylo vám uź jenom jedno jediné: $v$ tichosti odejít a nemané-vrovat. Mnohá z práv, která jste si osvojovali, vám nikdo nikdy nedal. Na zaćátku vaší epochy jste se vlády $v$ této zemi zmocnili násilím za ponoci zahraniční intervence, vládli jste opreni o bajonety a národ jste dokázali za pomèrnè krátkou historickou etapu pr̛̉ivést $v$ mnoha smèrech na pokraj zoufalství. Vytýkate nám emoce, planouci váśnè, obviñujete nás z rozvracé̌ství. Nemáte pravdu. Nevidín krvavé oći, ale rozjásané oči tisíce lidí, plné nadšeni. Lidé najednou na sebe zaćínají být hodní a ohleduplni, pomáhají si navzájem, jsou próitom $i$ plni chuti do pớádné práce a dokazují, jak vysoký morální kredit lze probudit jakoby mávnutín kouzelného proutku. Vy jste byli hluši a slepi, odmítali jste naslouchat hlasu zemè, která je i vaši rodnou zemí, nezajímalo vás, co se dèje vưkol v Evropé. Nenaslouchali jste skutečnému hlasu lidu, za nějž̀ jste tak ćasto skrývali potoky frázi, dokonale jste se odtrnli od obyčejného člověka a jeho starostí všedního dne a vzhliželi na svét $z$ výšin jakési bohorovné nedotknutelnosti. Lod pluje tam, kam se natoči kormidlo, prosté podle toho, kdo je u vesia. To veslo i kormidlo jste drželi - promiňte mi ten termín "setsakramentsky" dlouho a ted se divite, že se posádka lodi nemíní nechat utopit ve víru, který hrozi strhnout všechny, vás i nás. Nemížete se vymlouvat na to, že nesvítily majáky, ba dokonce hvézda od východu vám ukazovala správný smér, jenomže tohle svétlo vás bodalo do ớí, a tak jste si je raději zaclánéli. Sami jste tudiž na vině, vy jste byli kormidelníky, zatímco galejníküm nebylo dovoleno nic víc, než mlčet a potit trev. Nebudu - dále mluvit $v$ metaforách, ale nazúvat véci pravými jmény: ptát se vás, na co jste čekali. Snad na jinou už nelze spoléhat. Víte sami dobře, že tyto predstavy jsou dnes již zcela iluzorni. Copak to skuteçné nevidite, že naśe národy, odchované $v$ duchu demokratických tradic evropského domu se museji dívat na to, jak nás v procesu demokratizace socialismu predstihuji snad všechny sousední zemé. Ujíž́dí nám autobus, ale vám to nic neríiká, ba dokonce se zdás že vưbec nemíníte nastoupit. 0 co vám šlo - o blaho lidu nebo o pocit neomozené moci, na niž jste si během desítek zvykli jako na omannou drogu? Nevidite, jak se ze všech stran ozývaji varovné hlasy, hroutí se chatrné zdi doktrín $i$ paláce lž́i.

A ještě jedno varování, nepokoušejte se obalamutit lid nějakým novým trikem $v$ podobé přeformulovanǵch hesel a převlečenǵch loutek, ale jednejte, splňte požadavky studujících - slov už bylo dosti! To, že jste si zvolili nový ústredni víbor strany, je vnitrostranická záleźitost, to je abyste si neosobovali právo vuddé sily. Potom uvnitŕ strany si to vyridte po Vaśem. Do té doby, dokud nebudou vypsány svobodné volby, budeme hodnotit Vaše postoje podle rychlosti provedení a úcinnosti reforem. Jakoukoliv liknavostí $v$ tomto sméru ztrácite $v$ prvé ruadé vy sami další pozice na politické scénè a ujištujeme Vás, že budeme mít oći a uši otevrené. Podíl Vaśí úćasti na budoucí koalični vládĕ, a jinak si rešení znovanastolení české vlády zatím próedstavit nedovedu a nechci si už ted vytváret dopredu Vašín pŕistupen $k$ té puramidé problémú, které jste si po léta pilné reš́ili.

Kdybyste jste si tu pyramidu stavěli tak r̆́kajic na vlastnín písečku vnitrostranicky, je to Vaše véc, vzal to cert. Ale nemižete prece chtít, abyste tím ztratili vchod do naśeho spolećného domu a my museli lézt po hromosvodu oknem.

Cituji: víte o co jde Vám i nám - nikdo se již nemư̌ze vymluvit na to, že byl sveden a od této chvíle si každý z vás piše svưj kádrový posudek. To ner̉ikám já, ale cituji prosím slova doktora 


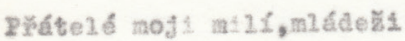

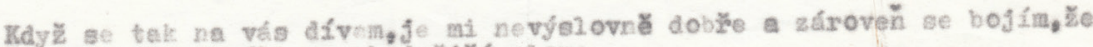
nenajdu pro tuto chvíli ne vhodnĕg gí slova.

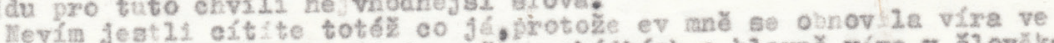

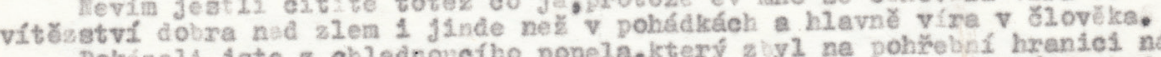

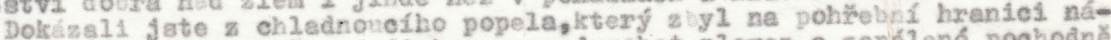
zodní hrdost1 a cti, vyluresat j1skru - rozdnychat plamen a zapálenó pochodnè roanést po celó zeni.

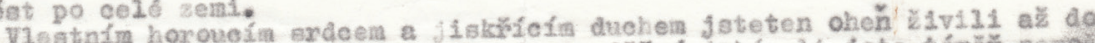

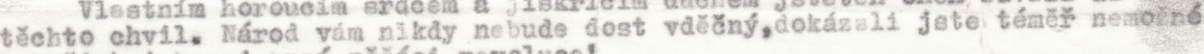

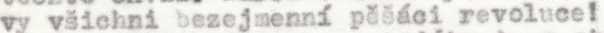

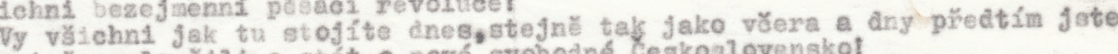
se vlestñ gaglour 111 o stát, o nové svobodné ceakosiovenskot

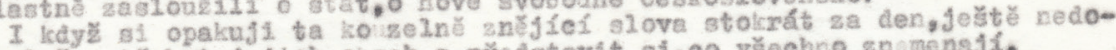

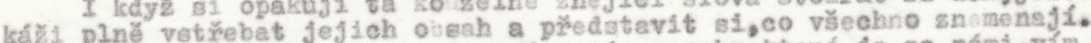

Nevím, jak fednou historie pojmenuje epoohu, která. je sa námi, vím však,

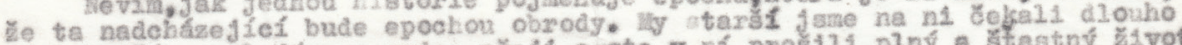

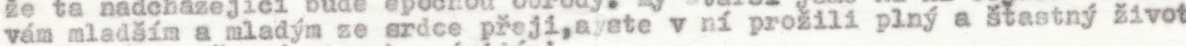
- prizinám ae, že vím trochu závilám!

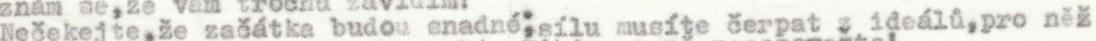

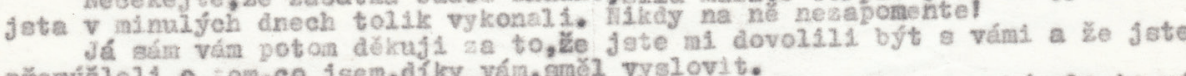

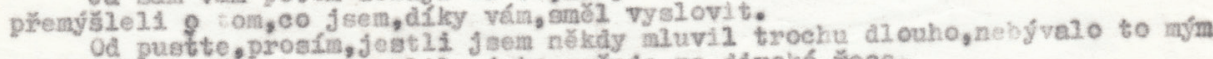

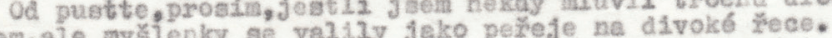

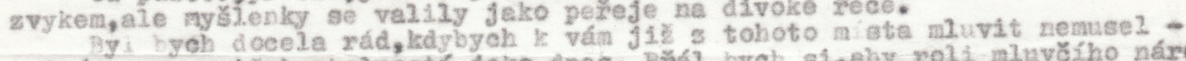
zejména ne ga trob okolností jako dnes. Pról byoh si, eby roli mluvóího národa pievzeli brsy ti lidé a instituce, ktex́ a které by j1mi mêli být - nově

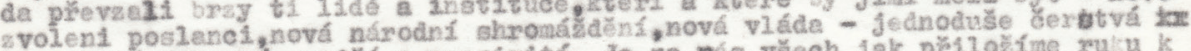

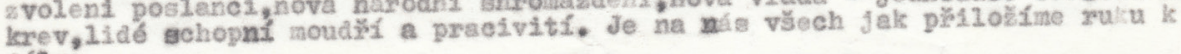
dilu:

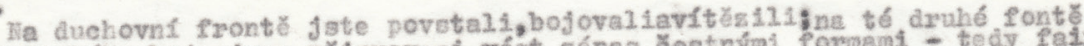
- politického boje Jome pripraveni vést zápas cestnými lormemi - tedy iaix-

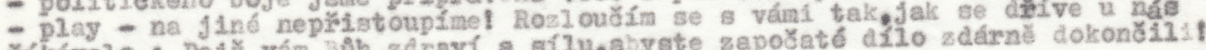

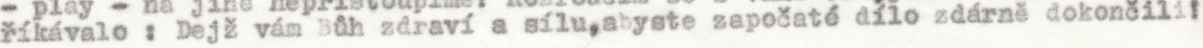


Pan Urbánek je však pouze jedním z předsedủ politických stran a KSč je pouze jednou $z$ politických stran navíc úplně zdiskreditovanou. Zásadně odmítáme účast generálnního tajemníka KSČ na jakémkoli jednání, které přísluší jen vládě ČSSR. KSČ reprezentuje jen bídu naši společnosti.

\section{Komentář k vystoupení předsedy vlády ČSSR v televizi 6. 12. 1989}

Již $v$ úvodu se zmiñujete, pane předsedo vlády, o tom, že nepovažujete složení federální vlády za optimální a pro všechny vyhovující a že podle potřeby může být zkvalitnována ...

Převedeno do jadrnější češtiny to znamená asi tolik jako:"vědomě jsme vyrobili zmetek, ale časem ho troc hu vylepšíme!"

Řečeno jinak: "Sestavili jsme vládu, která určitě vyhovuje vedení KSČ a je nám také jasné, že jsme $v$ dané situaci tímto krokem podráždili převážnou většinu národa."

Požádal jste představitele všech složek o návrhy, říkáte vy, chcete říci, že jste jich dostal tak málo, že z došlých jiná vláda sestavit nešla?

"Ne každému bylo vyhověno" - říkáte, "s tím se musí počítat", Někomu jste však přece jen vyhověl zcela! Mưžete nám to vysvětlit?

$\checkmark$ situaci, $v$ níž jsme, nesvědčí to, co jste volil, jako kvalifikované rozhodnutí státníka s rozhledem; připadá to více jako hra v kostky nebo výprodej partiového zboží na výročním trhu!

Dále říkáte, že není možné jednat pod nátlakem ultimát a že nemúžete jednat pod nátlakem jedné skupiny? Mohl byste tuto "skupinu" blíže specifikovat? - Pokud by to měla být nekomunistická část veřejnosti, což lze $z$ textu vycítit, nemáte zřej̉mě vưbec ponětí o veřejném mínění a doporučuji, abyste se rozhlédl dúkladněji kolem sebe!

Kompromisní řešení, které hledáte, musí být přijatelné pro všechny, pro celý národ - nejen osobně pro Vás nebo menšinu, pane ministerský předsedo!

Dále mluvíte o stupnování napětí, které by mohlo těžce poškodit naši ekonomiku; jste si vědom, že toto napětí stupnujete osobně Vy sám rozhodnutím, které jste učinil?

Jaké jistoty každodenního života lidí jsou $v$ nebezpeči - chcete říci, že pekaři nebudou péci chleba, zhasnou světla a nastane konec světa, když padne vláda, kterou jste sestavil?

Přestane-li fungovat nefungující státní správa, mám dojem, že se tak moc nezmění! Autobusy i vlaky budou jezdit i bez pana starosty - však on se někdo najde!

Kdybyste se snažil - jak říkáte - pane ministerský předsedo, každého pochopit, tak byste musel jednat jinak. S oblibou používáte pro většinu národa termínu "určitá část společnosti" - chybí tam už jen dodatek "svedená imperialistickou propagandou" - a jsme doma!

Jak můžete být zastáncem právního státu, když jste dal přednost při sestavování federální vlády representantům strany, která sama o sobě prohlašuje, že až příliš často jednala protiprávně. Za kým vlastně stojíte - za stranickým štítem nebo za národem?

Jestli se domníváte, že je nezákonné požadovat, by se státní moci vydali neschopní a zkorumpovaní - potom stojíte kdesi mimo dění; je 8. prosince 1909, pane ministerský předsedo, pozor na kalendáŕ!

Jste-li pro co riejrychlejší uspořádání demokratických voleb - tak my jsme raději pro svobodné volby, tomu cozumíme. Svérázné modely demokracií máme již snad jednou provždy za sebou! Kdo to zdržuje, my (?) - až tam úplně dole u pásủ ve fabrikách, u. rýsovacích prken, na stavbách a polích? Přijudte se podívat - bude to pro Vás poučné! 
Chtěl bych Vás ubezpečit, že nikdo - kromě páté kolony - neusiluje $\checkmark$ této zemi o hospodářský rozvrat; nesmíte však spojovat pojmy záměrně tak, abyste stavěl rovnítko mezi nesouhlas s navrženou federální vládou a anarchii.

Odmítnout nepřijatelné návrhy neznamená ani touhu po bezvládí, ani rozvrat - ba právě naopak!

Nelíbí se Vám neustále sílící proud požadavků? Bude jich nutně víc, řeky a veletoky a oprávněných! Vymést ten Augiášưv chlév - to bude fuška, to $s$ Vámi plně souhlasím!

Chudáci ministři a ředitelé, vždyt̃ oni budou muset žít v napěti - já si myslím, že budou muset pořádně "máknout", a bude se z nich kouřit! Ale my chceme ve vládě mít takové lidi, kteří na to mají, kterým budeme moci důvěřovat a kteří také jsou plni elánu.

Jsem přesvědčen, že jsou - máme je určitě mezi sebou, jenom je najít a dát jim možnost, aby ukázali, co dovedou.

"Nikdo, kdo má nebo cítí odpovědnost za republiku, by si neměl zahrávat s nervozitou" - říkáte Vy!

Jste nervózní Vy nebo ti, o nichž rozhodujete? Kdo větším právem, co myslíte? Nálady a sympatie se nemění v současnosti ze dne na den a už vưbec ne $z$ hodiny na hodinu - to je zásadně špatný odhad situace!

Protiřečíte si, pane ministerský předsedo $v$ zásadních věcech: odbornost kontra kádrový strop, útlum talentů a potřeba hlav osvícených - nějak se nám to zvrtlo, že?

Onen tolikrát slibovaný zásadní obrat by se měl rozběhnout právě ted̆ - v prosinci - tvrdíte $v y$, jestli to nevyjde, je to podle Vás naše chyba - těch druhých - nikoliv Vaše, že! Nebudeme si hrát na schovávanou! Vyvést společnost z krize je jistě složité - ale jak jednoduché ji bylo tam dostat a kdo ji tam dostal?

Domníváte-li se však, že k onomu zázračnému "vyvedení" stačí mít od 1.1. 1990 pouze fungující ekonomiku, dodržování zákonů a pravidelný pracovní rytrnus $v$ závodech a na školách - potom raději tu společnost nikam nevờte, mohla by zabloudit.

Změnit musíte celé politické klima $v$ zemi, to je úkol číslo jedna, pane ministerský předsedo; až lidé budou mít jistotu, že žijí ve svobodné zemi, lidsky, důstojně - potom věřte, že budou ochotni i utáhnout si opasek o pár dírek a "makat" - jakékoliv opomenutí v tomto smyslu však múže znamenat nejen konec iluzím o štastném životě zítra - nýbrž i pro budoucí generace.

RNDr. Mojmír PROKOP

\section{Vážení občané,}

je nesporné, že někteří poslanci zastupitelských orgánů zklamali dưvěru nás, voličủ. Máme na mysli např. tyto poslance Federálního shromáždění: Jakeš, David, Fojtík, Bilak, Hofman, Štěpán, Václavík, Kabrhelová, Češka, Slavík a dalši. Právní úprava pro odvolání poslancủ je poplatná době, ktecou se snažíme změnit a tak postup je velmi složitý a prakticky nepoužitelný. y § 99 zákona o volóch do Federálního shromáždění se uvádí, že poslanec, který zklamal dưvěru voličú nebo který se dopustil nedůstojného činu, mủže být odvolán. Zkompromitovaní poslanci nenašli $v$ sobě dostatek odvahy a síly přiznat si nezvratnou skutečnost, že ztratili ve smyslu zákona právo být ve Federálním shromážděni. Nevzdali se svého mandátu sami. Je potom odpověd-ností příslušného orgánu předložit předsednictvu Federálního shromáždění návrh na jejich odvoláni. Tyto orgány však jakoby nebraly přání a vưli voličủ na vědomí a mlčí. Domníváme se, že je třeba dát jak těmto poslancím, tak i příslušným orgánům hmatatelný dưkaz jednoznačné vỉle a próní obyvatelstva, které zni: Nemáte náš mandát ! 